\title{
Household and Drinking Water Supply and Water Consumption in Kilis Province
}

\author{
Yunus Ozturk (Corresponding Author) \\ Department of Civil Engineering, Engineering Faculty, Kilis 7 Aralık University, Turkey \\ E-mail: ynsemre@kilis.edu.tr \\ Huseyin Cagan Kilinc \\ Department of Civil Engineering, Engineering Faculty, Hasan Kalyoncu University, Turkey \\ E-mail: cagan.kilinc@hku.edu.tr
}

This research was supported by Kilis 7 Arallk University Scientific Research and Projects Unit (BAP)

\begin{abstract}
In this research, current drinking and household water system of Kilis province has examined. This study aims to determine water consumption of each person in order to using current water resources more efficiently. Examination has also related to current water potentials, water supply line, water storages and water distribution lines. The water (household and drinking) usage of the city of Kilis is supplied by domestic and wells in the city. The water, supplied from underground and ground resources is using in residence, public corporation, business and industrial sectors. Measurable and immeasurable water amounts distributed to city are compared then water usage amounts rated to population which is important parameter of estimation of water usage in order to find water usage per capita in Kilis province. Finally, water consumption per capita is expected to be $171 \mathrm{lt} /$ day (gross) 79 lt/day (net) with roughly around \%53 losses.
\end{abstract}

Keywords: Kilis province, Drinking and household water, Water need, Water losses, Water supplying.

DOI: $10.7176 / \mathrm{JSTR} / 5-2-41$

\section{INTRODUCTION}

Water is one of the most important substances for all living and non-living beings. As it is known, living beings cannot survive for a very long time without air according to their biological characteristics. For example, people can live for up to 5 minutes without air, 40 days without food, 7 days without water [1, $2,3]$. Since long ago, water is at least as important as life. The mountain, the stone, the soil and the shelter, the road, the park, the garden etc. many phenomena known as inanimate life seem to have no meaning without water. The water that is so necessary for all living and non-living beings to survive their lives is supplied from the world's water resources. Taking water resources into consideration, it can be said that the world of water with $3 / 4$ of us has very little water resources available and that the distribution of these resources is not very stable. This necessitates more regular and efficient use of clean and potable water resources, which are already low. The total water in the world is approximately $1386 \times 10^{6} \mathrm{~km}^{3} /$ year. About $97 \%$ of total water $\left(1338 \times 10^{6} \mathrm{~km}^{3} /\right.$ year $)$ is salty water. More than $68 \%$ of the remaining freshwater resources are trapped in ice and glaciers $(3 \%)$. The other $30 \%$ of fresh water is placed in underground as a underground water. The amount of surface freshwater resources such as rivers, lakes, etc., which constitute the majority of the water source that people use every day, is only $0,72 \%\left(93120 \times 10^{6} \mathrm{~km}^{3} /\right.$ year $)$ of the total water in the world. In other words, the amount of fresh water in the world is very limited. The total amount of water that can be used in Turkey is $\left(112000 \times 10^{6} \mathrm{~m}^{3} /\right.$ year $)$, which means that $\left(95000 \times 10^{6}\right.$ $\mathrm{m}^{3} /$ year) for the country, $\left(3000 \times 10^{6} \mathrm{~m}^{3} /\right.$ year) for the countries coming from the neighboring countries, $\left(14000 \times 10^{6} \mathrm{~m}^{3} /\right.$ year $)$ underground waters. In our current conditions, our surface water potential of $\left(95000 \times 10^{6} \mathrm{~m}^{3} /\right.$ year $)$ can only be utilized from $\left(27500 \times 10^{6} \mathrm{~m}^{3} /\right.$ year $)(29 \%)$. The utilized water potential is $\left(20900 \times 10^{6} \mathrm{~m}^{3} /\right.$ year $)(76 \%)$ in irrigation, $\left(3850 \times 10^{6} \mathrm{~m}^{3} /\right.$ year $)(14 \%)$ is used by the municipalities as 
drinking water and $2750 \times 10^{6} \mathrm{~m}^{3} /$ year $(10 \%)$ in the industry. It is taking consider into that the water demand in Turkey will increase by $75 \%$ in agriculture and $260 \%$ in drinking and utility water by 2030 [4]. The total amount of water available in Kilis province is $\left(252,09 \times 10^{6} \mathrm{~m}^{3} /\right.$ year $),\left(233,33 \times 10^{6} \mathrm{~m}^{3} /\right.$ year $)$ in rivers and $\left(18,76 \times 10^{6} \mathrm{~m}^{3} /\right.$ year) in lakes are accumulated in groundwater [5, 6]. Providing drinking and household water needs of residential units is now possible with costly facilities. These facilities can only be carried out economically in accordance with their purpose, but with good planning. The elements of this planning can be summarized as the identification of the water needed, the availability of adequate water resources to meet this need, the economical recruitment and distribution of water from the source to treatment plants. Water resources management in the world and in Turkey and the supply of water resources to the places have been taken over by these engineering services. When only water losses and seepages are taken into consideration, it is known that sometimes the excess of half of the water supplied with such costs is lost through illegal use and the result is occured as very serious economic bills. In addition, unintentional consumption of water in the water resources is very important both in province and in the waste water of the nature. Care should be taken in the management of the water transmission and distribution water treatment plants as well as the water needs of the province in this consideration. Kilis province drinking and household water plants have been made and renewed in various dates by city growth and evaluation according to need. The first drinking and household water project of the city is Ilbank Bank regulation was carried out in 1976. It has come to the present day by making additions to this project. Considering the current distribution system and data, it is seen that $60-70 \%$ of the losses from the water network in Kilis province are observed. In this research, the current water supply system and the studies done to provide drinking and household water needs of people living in the city center of Kilis and other parts of the city have been examined. By taking advantage of the data obtained from the examinations made, the measures to be taken in order to make the water supplied to the city more efficient and ergonomic are evaluated.

\section{MATERIAL \& METHOD}

\subsection{Material}

Kilis was founded in 1995 by the Turkish Grand National Assembly. It is in the transition area from the Mediterranean Region to the Southeastern Anatolia Region and is a neighboring border city with Gaziantep and Hatay provinces and Syria. The location is between $36^{\circ} 45^{\prime}$ and $37^{\circ} 45^{\prime}$ and between $37^{\circ}$ $00^{\prime}$ and $36^{\circ} 45^{\prime}$ longitudes. The average altitude of the city ranges between $600-750 \mathrm{~m}$ [7]. The province has a surface area of $1521 \mathrm{~km}^{2}$ and its main mountains are Kurt, Darmik, Hazil, Karruca, Kartal, Arapdede and Sof; its main rivers are Afrin Stream and Sabun Water; The main plains Kilis and Elbeyli; Provinces Musabeyli, Elbeyli, Polateli; Kilis is an old city that dates back to the Middle Bronze Age [8]. The population of Kilis is 128,586 according to the results of Adolescent Population Census (APC) in 2013, 93640 people live in the city while 34,946 live in the villages. The percentage of people living in the city is $72,8 \%$, the ratio that living in the village is $27,2 \% .49,6 \%$ of the provincial population is under 25 years old, $42,7 \%$ is between $25-65$ years old, $7,7 \%$ is over 65 years old. According to the ABPRS data, the population density of the province is 90 people in $\mathrm{km}^{2}$, below the population density of 100 people. The annual population growth rate is $33,7 \%$. The rate of net migration of the province in 2012-2013 has been $3,15 \%$. Kilis has 4 districts and 137 villages [9].

\subsection{Method}

This research was carried out in order to estimate the water use of current water resources of Kilis correctly, to determine the water losses and illegal use correctly and to estimate the water need more realistically in future projects.

In order to determine the net consumption of drinking water in Kilis and the gross amount in 1/percapi/day, water supplied from the network to the city network and the amount of water consumed from the network and its subscriptions were taken from the records of the Waterworks Directorate of Kilis Municipality in 2009-2013. In addition, consumption from June 2012 to May 2013 (Research Period) was taken as the period, and it was evaluated as monthly data. In this view, Kilis province' figures for these dates were obtained from the TUIK population records. In addition, data on the use of groundwater (Underground water level), which is the basis for off-grid water usage, has been obtained from public institutions such as DSI 20th Regional Directorate, Kilis Special Administration Directorate. As a first step in the determination of water use quantities, the present water consumption situation of the province has been examined in detail. This review is based on the following headings [10]. The analysis of total water consumption in the research area was carried out by investigating the changes between the quantity of 
water consumed and measured by the subscriber and the amount of water supplied to the city network outside the network and where the consumed water was used.

\section{RESULTS AND DISCUSSION}

\subsection{Urbanism}

Due to the fact that Kilis is a very old place, the zoning plan has been continuously updated and changed many times by adapting to the conditions of the day. The current development plan was carried out by İl Bank in 2006. This plan covers all of the current place and has been prepared in such a way as to allow the city to grow in the northeast direction. The city is based on the 2005 population of 127,000 persons envisaged in the GAP Master Plan based on the 1990 population of 82882 people. The plan covers a total area of 1342,52 hectares. A total of 513,10 ha is planned as a residential area, of which 319,23 ha of the plan is residential and 183,87 ha of which is a development area. The average density is 95 people $/ \mathrm{km}^{2}$. Since Kilis is a historic settlement, there are sections under the protection of the current city structure as a protected area. Administrative structure was established by dividing the existing settlement units in the province into a total of 77 districts [11].

\subsection{Population}

The population of Kilis is 128,586 according to the results of Adolescent Population Census (APC) in 2013. The population census results of the province in different years are given in (Table 3.1). [9]. As a result of the crisis that started in Syria in 2011, Syrian asylum-seekers began to come to Kilis from 2012 onwards. Especially since 2013 there has been an intense increase in the numbers of asylum seekers. For this reason, it was necessary to evaluate the city center and the Syrian asylum seekers at Öncüpınar migration camp within the scope of the project. This has created serious problems in sharing the available resources. in the province. The city center population given in (Table 3.1). has been added to Syrian asylum seekers located in the Öncüpınar camp and city center for 2013 [12]. Given the population and population growth processes in Table 3.1, there is generally an increase in the provincial population in parallel with the world and national population. However, in 1990-2000 population growth in province and city center was negative. This can be explained by the fact that some of the villagers who were connected to Kilis prior to the province of Kilis in 1995 were connected to the province of Gaziantep. It is understood from Schedule 3.1 that there is an unforeseen increase in the population of the city center of 2013 due to the concentration of Syrian asylum seekers. As can be seen, it should be considered that there are many positive or negative developments in the population projections which are not easy to estimate the future population predicted when the infrastructure projects of the settlements are made.

Table 3.1 Country, province and city center population and annual population growth rates according to years of census.

\begin{tabular}{|r|r|r|r|r|r|r|}
\hline \multirow{2}{*}{ Year } & \multicolumn{2}{|c|}{ Country-wide } & \multicolumn{2}{c|}{ Province-wide } & \multicolumn{2}{c|}{ City-Center } \\
\cline { 2 - 7 } & Population & $\begin{array}{r}\text { Increasing } \\
\text { Rate (\%) }\end{array}$ & Population & $\begin{array}{r}\text { Increasing } \\
\text { Rate (\%) }\end{array}$ & Population & $\begin{array}{r}\text { Increasing } \\
\text { Rate (\%) }\end{array}$ \\
\hline $\mathbf{1 9 6 5}$ & 31391000 & - & 75092 & - & 38095 & - \\
\hline $\mathbf{1 9 7 0}$ & 35605000 & 25.50 & 83913 & 22.50 & 43438 & 26.60 \\
\hline $\mathbf{1 9 7 5}$ & 40348000 & 25.30 & 92759 & 20.20 & 54055 & 44.70 \\
\hline $\mathbf{1 9 8 0}$ & 44737000 & 20.90 & 95419 & 5.70 & 58335 & 15.40 \\
\hline $\mathbf{1 9 8 5}$ & 50664000 & 25.20 & 101818 & 13.10 & 59876 & 5.20 \\
\hline $\mathbf{1 9 9 0}$ & 56473000 & 21.90 & 121752 & 36.40 & 82882 & 67.20 \\
\hline $\mathbf{2 0 0 0}$ & 67804000 & 18.50 & 114724 & -5.90 & 70670 & -15.80 \\
\hline $\mathbf{2 0 0 7}$ & 70256000 & 5.10 & 118457 & 4.60 & 77706 & 13.70 \\
\hline $\mathbf{2 0 1 0}$ & 73723000 & 16.20 & 123135 & 13.00 & 82109 & 18.50 \\
\hline $\mathbf{2 0 1 3}$ & 76668000 & 13.10 & 128586 & 14.50 & 115886 & 121.70 \\
\hline
\end{tabular}

*City center population included Syrian migration (included Öncüpınar camping). 


\subsection{Current Water Potential}

Water is supplied from various sources such as Seve Dam, Narlıca source, Öncüpınar Deep Wells, deep wells with licensed and unlicensed types, packed water and street fountains in various types and depths in order to provide the drinking and usage water needs of Kilis province $[6,13]$. This water is delivered to the consumers by means of distribution system (city water network) or direct transmission route. The water distributed by the city water network can be measured. However, water that is directly conveyed or consumed cannot be measured. The measurement of water use in the residential, public, commercial and industrial sectors made off-grid was carried out with different approaches developed according to the situation. Measurement of water obtained from licensed or unlicensed wells and consumed through nongrid use; Water was taken from the wells for an average of 10-12 hours per day. Between 1990 and 2013, a total of 115 licensed wells were opened in the central district of Kilis and a total of $3,88 \times 10^{6} \mathrm{~m}^{3} /$ year of water was withdrawn from them. The amount of unlicensed wells opened in this period is not known precisely and the total amount of groundwater withdrawn from the sub-basin of the central province of Kilis is $6,39 \times 10^{6} \mathrm{~m}^{3} /$ year, and when it is deducted from the total number of $3,88 \times 10^{6} \mathrm{~m}^{3} /$ year withdrawn from the licensed wells The remaining $2,51 \times 10^{6} \mathrm{~m}^{3} /$ year was considered to have been drawn from unlicensed wells $[6,13,14]$. The average water consumption per tap in the street fountains is assumed to be $4 \mathrm{~m}^{3} /$ day [15]. There are approximately 45 street fountains in Kilis and a total of 90 taps in these fountains [13]. It is accepted that $0,113 \times 10^{6} \mathrm{~m}^{3} /$ year of water from the street fountains in Kilis is consumed as drinking and potable water in this frame. It has been accepted that the whole of the water supplied without the network (without loss and illegal use) is consumed. On the other hand, it is understood that $5 \%$ of the water supplied for the use of the network is lost when the amounts of water entering and leaving the treatment plant are taken into account. The amount of water supplied and given in the survey period is given in (Table 3.3.) $[6,13,14]$. It is seen that a total of $13,79 \times 10^{6} \mathrm{~m}^{3} /$ year of water supplied from (Table 3.3.) $7,25 \times 10^{6} \mathrm{~m}^{3} /$ year is in the network and $6,54 \times 10^{6} \mathrm{~m}^{3} /$ year is out of the network. Daily average water needs of the settlements vary between 200-300 1/per capita/day in Turkey and 300-400 1/per capita/day in the world $[11,16]$. For Kilis, the average daily water requirement per person (including special needs) of 300 1/per capita/day was considered according to the conditions of the research period. According to this consumption value, total water requirement is $18 \times 10^{6} \mathrm{~m}^{3} /$ year in Kilis' research period. Kilis is supplied with a total of $14,07 \times 10^{6} \mathrm{~m}^{3} /$ year of water during the research period. Considering the national and international criteria, the water supplied to the province is not enough. In the province where natural water resources are insufficient, it is necessary to take measures to save water loss and leakage.

\subsection{Water Supply}

In order to meet the drinking and utility water needs of residential units, water supplied from underground and surface water sources is delivered to consumers as in-network and out-of-network usage. In general, while domestic water consumption values constitute the largest share of domestic water consumption, industrial, public and commercial water consumption is the most important for non-network use. When the water consumption values are examined, it is seen that $92,34 \%$ of the total water consumption from the network in the province is distributed in residential buildings, $6,15 \%$ in public, $1,40 \%$ in commercial and $0,11 \%$ in industrial consumption according to the survey period measurements seen. According to this, it can be said that the largest share of water consumption from the network belongs to industrial consumption, the smallest share of residential consumption. In Kilis, the amount of illegal water consumption from the network is calculated as approximately $0,15 \times 10^{6} \mathrm{~m}^{3} /$ year, assuming $5 \%$ of the meter usage. In this way, it is assumed that in addition to the above calculated values from the network due to broken clocks and illegal usage, an additional $0,46 \times 10^{6} \mathrm{~m}^{3} /$ year water is drawn annually. According to the total water consumption values made during the research period in the province; Per capita water consumption was found to be net $171 \mathrm{l} /$ per capita/day and gross 326 1/per capita/day. The average per capita water consumption in the world is 1/per capita/day net, 900 1/per capita/day net, 250 1/per capita/day and $400 \mathrm{l} /$ per capita/day in Turkey[16]. If water consumption values of Kilis are low according to these water consumption values, it is acceptable when considering the socio-economic structure and population of the province. However, it is known that the consumption of water in the network is very low based on the amount of water given to the city. Water consumption from non-grid sources should be regarded as a significant loss in terms of national wealth, in terms of provincial economy, even if it meets the needs of the city. It has been understood that there has been a significant increase in water subscriptions in recent years from the records of Kilis Municipality Water Works Branch Directorate. It should be accepted that the increase in the number of subscribers will increase even more when the urbanism and socio-economic structure in Kilis is expected to accelerate in the coming period. Due to the crisis in Syria in 2011, Kilis 
had to accept Syrian refugees intensively and increasingly since 2012. Although this situation is based on the principle that infrastructure services in the city are taken as free of charge for migration seekers.

Table 3.2 Sectoral distribution of Kilis province manufacturing industry.

\begin{tabular}{|c|c|c|}
\hline SECTORS (TYPES OF INDUSTRY) & ACTIVITY AREA & $\begin{array}{l}\text { COMPANY } \\
\text { NUMBERS }\end{array}$ \\
\hline \multirow{10}{*}{ FOOD } & Fame & 12 \\
\hline & Pounded wheat & 1 \\
\hline & Milk Productions & 2 \\
\hline & Pellet feed & 1 \\
\hline & Candy & 3 \\
\hline & Catering Sector & 5 \\
\hline & Spices & 2 \\
\hline & Ethyl Alcohol Industry & 1 \\
\hline & Pulse Grain & 1 \\
\hline & Butchery & 1 \\
\hline \multirow{3}{*}{ WEAVING AND CLOTHING } & Sewing Cotton & 3 \\
\hline & Jersey & 3 \\
\hline & Garment Industry & 4 \\
\hline PAPER & Sheeter & 1 \\
\hline PLASTIC & Plastic things & 1 \\
\hline PETROLEUM PRODUCTS & Plastic things & 3 \\
\hline \multirow{2}{*}{ COSMETIC CLAY AND CEMENT. } & Bric-briquet & 2 \\
\hline & Ready-mixed concrete & 5 \\
\hline IRON AND STEEL & Rounded iron & 1 \\
\hline \multirow{3}{*}{ NON-IRON METALS } & Gold processing & 1 \\
\hline & Solar Energy Panel & 1 \\
\hline & Mining & 1 \\
\hline MINERAL GOODS & Nailing & 1 \\
\hline OTHERS & Cleaning products & 2 \\
\hline \multicolumn{2}{|l|}{ TOTAL } & 72 \\
\hline
\end{tabular}


Table 3.3 Total amount of water supplied / given to the city.

\begin{tabular}{|c|c|c|c|c|c|c|}
\hline \multirow{2}{*}{ Number } & \multirow{2}{*}{$\begin{array}{l}\text { Water } \\
\text { Resource }\end{array}$} & \multirow{2}{*}{ Usage } & \multicolumn{2}{|c|}{ Water supply } & \multicolumn{2}{|c|}{ Given water to province } \\
\hline & & & $10^{3} \mathrm{~m}^{3} / \mathrm{day}$ & $10^{6} \mathrm{~m}^{3} /$ year & $10^{3} \mathrm{~m}^{3} / \mathrm{day}$ & $10^{6} \mathrm{~m}^{3} /$ year \\
\hline 1 & Seve Dam & \multirow{3}{*}{$\begin{array}{l}\text { Water } \\
\text { usage in } \\
\text { water- } \\
\text { network }\end{array}$} & 15.81 & 6.05 & 15.57 & 5.77 \\
\hline 2 & $\begin{array}{l}\text { Narlica } \\
\text { Resource }\end{array}$ & & 3.89 & 1.42 & 3.89 & 1.42 \\
\hline 3 & $\begin{array}{l}\text { Öncüpınar Deep } \\
\text { Wells }\end{array}$ & & 0.16 & 0.06 & 0.16 & 0.06 \\
\hline \multicolumn{3}{|l|}{ Total } & 19.87 & 7.53 & 19.62 & 7.25 \\
\hline 1 & Licensed wells & \multirow{4}{*}{$\begin{array}{l}\text { Water } \\
\text { usage out } \\
\text { of the } \\
\text { water- } \\
\text { network }\end{array}$} & 10.63 & 3.88 & 10.63 & 3.88 \\
\hline 2 & $\begin{array}{l}\text { Unlicensed } \\
\text { wells }\end{array}$ & & 6.88 & 2.51 & 6.88 & 2.51 \\
\hline 3 & $\begin{array}{l}\text { Packaged } \\
\text { (commercial) } \\
\text { waters }\end{array}$ & & 0.055 & 0.02 & 0.055 & 0.02 \\
\hline 4 & Street fountains & & 0.36 & 0.13 & 0.36 & 0.13 \\
\hline \multicolumn{3}{|l|}{ Total } & 17.93 & 6.54 & 17.93 & 6.54 \\
\hline \multicolumn{3}{|c|}{ General Total } & 37.80 & 14.07 & 37.55 & 13.79 \\
\hline
\end{tabular}

\section{Conclusion}

The existing development plan should be revised taking into consideration the developments in the socioeconomic structure of the province. Even considering the difficulty of implementing the plan for the existing settlements, the plan should be prepared by evaluating the actual settlements according to the principle of "accepting the actual situation" from the legal point of view, even though it is not in line with the city planning procedures. In the process of implementing the new plan, different concepts of interest should be avoided in practice by adhering to the city's development process and the concept of modern urbanism. It is observed that the province has a continuous increase in general when the daily population movements from the past are evaluated. However, it should be considered that a possible administrative structure or socio-economic development may affect the population movements. Therefore, given the Syrian crisis in the coming years in Kilis, it should be known that there will be a population increase above normal. Based on the research period, it is found that the total water provided for the city is $14,07 \times 10^{6}$ $\mathrm{m}^{3} /$ year, $7,53 \times 10^{6} \mathrm{~m}^{3} /$ year for the grid and $6,54 \times 10^{6} \mathrm{~m}^{3} /$ year for the off-grid. This shows that a large amount of $46,5 \%$ of drinking and drinking water consumed in Kilis is provided from non-grid sources. Consumption of this water by users without subjecting it to any treatment or disinfection may cause serious health problems. The absence of such a problem today does not mean that it will not happen after this day. Also, as you know, water resources are our natural resources. The right to use natural resources belongs to the public. The natural consequences of socio-economic developments in the province are increasing demands for infrastructure services. We monitor this from the increase in the number of subscribers on the demand for drinking and using water. When assessed in the expectations of the Syrian asylum seekers and the university, this demand should be accepted to increase with rapid acceleration. Taking into account the project service durations considered in the infrastructure projects, although the project construction process has been planned considering the unpredictable developments in the future, this necessitates revision of project data for Kilis province. According to records of Kilis Municipality Water Works Branch Directorate; Based on the research period, 68 1/per capita/day of household water consumption, 11 1/per capita/day of non-network consumption and 79 1/per capita/day of residential consumption are obtained from the network. This amount of consumption was found to be very low compared to the standard water consumption per capita. Considering the main factors affecting water consumption, it can be said that the consumption of residential water per capita in the province will increase in the coming 
days. Since domestic water consumption accounts for the largest portion of the total consumption from the network $(92,34 \%)$, what needs to be done to increase the amount of water given in the direction of positive developments in Kilis's socio-economic structure. As a result, when the water consumption values in Kilis are compared with the amount of water given to the city, existing water supply and drinking water sources will be sufficient for many years without applying the limited water program when water losses and leaks are prevented. In addition, off-grid water use should be controlled and water supplied from many underground water sources should be distributed through the network. This situation will prevent both possible health problems and will contribute significantly to the urban economy. The amount of water supplied to the city network must be measured (including water supplied to the network outside the treatment), meter readings must be made in a regular and accurate manner. The measured values made from meters and water supplied to the network must be checked continuously. In this way, the use of illegal water can be prevented in particular. Uncirculated consumption from the network should be measured absolutely even if it is not purchased with a price. Water transmission and distribution lines should be controlled continuously to prevent water losses.

\section{References}

Anonymous, 2011a. "Basic Life Support" (Ministry of Education), MEGEP Yayınları, Yayın no: 720 S00047 http://www.megep.meb.gov.tr, Ankara.

Anonymous, 2012a. "Natural Life Conservation and Wildlife Survival Techniques" SDÜ, Lecture Note, Isparta.

Williams, M. H., 2004. "Nutrition for Health, Fitness \& Sport” 7th, ISBN:0072441704, Published by Science/Engineering/Math.

Demir Y., 1993. "Turkey and the Journey Towards Thirst", 22 Mart 1993 World Water Day Conference, OMÜ, Agricultural Faculty, Samsun.

Anonymous, 2012b. "Environmental Report", Kilis, Republic of Turkey Ministry of Environmen and Urbanisation, Kilis.

Anonymous, 2013a. "Kilis Ili Underground Water Potential Research Report” DSİ 20. Regional Directorate, Kahramanmaraş.

Anonymous, 2011b. "Environmental Report”, environment and urban ministry of Kilis, Kilis.

Harbalığlu, M., Özel, G. ve Birol, E., 2013. "Evaluation of Kilis Province in terms of Rural Tourism Potential and Socio-Economic Development", International Journal of Social and Economic Sciences, ISSN: 1307-1149, E-ISSN: 2146-0086, www.nobel.gen.tr.

Anonymous, 2013b. “Selected Index of Kilis”, TÜIK(Turkish Statistical Institute), ISBN 978-975-196166-2, Ankara.

Öztürk Y., ve Orhan H., 2000. "Factors Affecting Residential Water Consumption in Kahramanmaras Province”, KSÜ Science and Engineering Journal, Volume:2, Number:1, s:138-148, Kahramanmaraş.

Anonymous, 2011c. "Hydrological Report of Kilis Province”, İl Bank Ministry, Ankara.

Anonymous, 2013c. "Syrian Asylum seekers in Turkey 2013 Field Survey Results" Prime Ministry, Disaster and Emergency Management (AFAD), Ankara.

Anonymous, 2013d. "Kilis Province Water Consumption Records”, Kilis Municipality Water Affairs Branch Directorate, Kilis. 
Anonymous, 2013e. "Kilis Local Water Resources Records", Kilis Governor's Office Special Administration, Kilis.

Anonymous, 1976. "Water Supply Project and Feasiblity report of Bursa Province, Volume: 1", Middle East Technical University, Labratory of Water Supply, State Water Works, Ankara.

Karakaya, N., ve Gönenç, E., 2007. "Water Consumption in Turkey and in the World”, Environmental Management Symposium, İgem Portal, Ankara. 